УДК $327: 341.7$ HАТО

DOI: $10.26693 /$ ahpsxxi2020.02.076

\title{
ЕВОЛЮЦІЯ ПУБЛІЧНОї ДИПЛОМАТІї НАТО
}

\author{
Олеся Звездова, \\ e-mail: zvezdova-ir@ukr.net \\ ORCID: https://orcid.org/oooo-ooo1-9664-5257 \\ Чорноморсъкий національний університет імені Петра Могили, \\ Украӥна, 54оо3, м. Миколаїв, вул. 68 Десантників, 10 \\ Альона Мокряк, \\ e-mail: mokryak.alena@gmail.com \\ ORCID: https://orcid.org/oooo-ooo2-3679-0919 \\ Чорноморсъкий національний університет імені Петра Могили, \\ Україна, 540о3, м. Миколаїв, вул. 68 Десантників, 10
}

У сучасних умовах публічна дипломатія стае важливим структурним компонентом стратегї провідних акторів світової політики, до числа яких належить Організація Північноатлантичного договору (НАТО). Можна виділити кілька періодів, для кожного з яких характерні свій блок цілей і завдань публічної дипломатї̈, спрямованість їх розвитку відповідно до еволюиї стратегічних установок блоку як моделі забезпечення колективної безпеки, такі як період холодної війни, період безпосереднъо після закінчення холодної війни (або «період партнерства $і$ співпраці» за термінологією НАТО) $і$ період глобалізації (або «період нових умов безпеки після 11.09.2001» за термінологією НАТО).

Публічна дипломатія НАТО включає сукупність форм і методів, сил і засобів пропаганди, а також способів групового спілкування, використовуваних для роз'яснення політики НАТО, сприяння у проведенні війсъкових операцій $i$ вирішенні інших завдань. Дана діяльність спрямована на формування «правильного розуміння» цільовими аудиторіями практичних кроків НАТО з підтримки стабільної обстановки у кризових регіонах, що виключає прояв ворожості з боку місцевого керівництва та населення щодо війсъковослужбовців блоку.

Ключові слова: НАТО, публічна дипломатія, інформаційна стратегія, органи публічної дипломатї

Постановка проблеми. Сучасний розвиток системи міжнародних відносин, тісно пов'язаний з прискоренням процесів глобалізації та появою нових глобальних загроз, робить необхідним міжнародне обговорення принципів політичної організації світу. Найважливішу роль у цьому випадку відіграють механізми публічної дипломатії, головним завданням яких є посилення стримуючого фактору силового вирішення проблем у міжнародних відносинах. У сучасних умовах публічна дипломатія стає важливим структурним компонентом стратегії провідних акторів світової політики, до числа яких належить Організація Північноатлантичного договору (НАТО).

Аналіз попередніх досліджень. Особливості еволюції публічної дипломатії НАТО досліджують як вітчизняні, так і закордонні науковці. У даному випадку варто відзначити праці українських дослідників А. Баровської ${ }^{1}$ та С. Гуцала². Се-

\footnotetext{
${ }^{1}$ Баровська, А.В. (2015). Стратегічні комунікації: досвід НАТО. Стратегічні пріорите$m u, 1$ (34), 147-152.

2 Гуцал, С. (2015). Публічна дипломатія та стратегічні комунікації: визначення концептуальних основ. Міжнародні відносини. Серія «Політичні науки», 9. Retrieved from
} 
ред представників зарубіжних науковців варто відзначити роботу А. Манойло3, де автор акцентує увагу на психологічних операціях як важливому політичному інструменті, який досить активно застосовується суб’єктами міжнародного права, серед яких є і НАТО. Також цікавою є праця 3. Паговські4, в якій науковець висвітлює залучення потенціалу актуальних мережевих платформ, а саме соціальних сторінок у Facebook, Twitter, YouTube, Google+ до публічної дипломатії HATO.

Методи та прийоми дослідження. Методологічну основу роботи складають сукупність філософських та наукових підходів до розуміння проблем у поєднанні зі спеціальними методами досліджень, а саме: порівняльного аналізу, періодизації, класифікації, систематизації документальних фактів тощо. Огляд наукової літератури здійснено за структурно-тематичним і хронологічним принципами.

Виклад основного матеріалу. В історії НАТО можна виділити декілька періодів, кожен з яких мав власний напрям реалізації публічної дипломатії у питанні забезпечення колективної безпеки. Досить усталеною $\epsilon$ наступна періодизація розвитку альянсу: 1) період холодної війни; 2) період безпосередньо після закінчення холодної війни (або «період партнерства і співпраці» за термінологією НАТО); 3) період глобалізації (або «період нових умов безпеки після 11.09.2001» за термінологією НАТО)5.

Публічна дипломатія НАТО у цей період була орієнтована, головним чином, на вирішення завдань щодо зміцнення внутрішньої єдності блоку i, перш за все, трансатлантичних зв’язків, формуванню образу ворога в особі СРСР та Організації Варшавського договору. Одночасно здійснювалися активні підривні дії, спрямовані проти головних супротивників. У державах-членах НАТО проводилася цілеспрямована робота по всебічному розширенню вкладу союзників у сукупний потенціал альянсуб.

Закінчення холодної війни поставило публічну дипломатію НАТО перед необхідністю вирішення спектра завдань, що раніше не зустрічалися. У 1991 і 1999 pp. були прийняті стратегічні концепції НАТО, в основі яких лежали політичні та військово-стратегічні установки стратегії «гнучкого реагування», доповнені з урахуванням зміни військово-політичної обстановки після закінчення холодної війни. Виконання їх проходило на тлі різкого ослаблення економічного та військового потенціалу Росії й зміцнення позицій США як єдиної наддержави7.

У цих умовах найважливішим завданням було обгрунтувати як для внутрішніх, так і для зовнішніх об’єктів впливу необхідність зберегти альянс за відсутності колишньої радянської загрози, а незабаром і потребі розширення НАТО.

Одночасно значні зусилля публічної дипломатії були спрямовані на підтримку та роз'яснення ключових ініціатив щодо формування мережі партнерства: Ради євроатлантичного партнерства, програми «Партнерство заради миру» (РEАП/ПЗМ) та інших нових ініціатив альянсу: Середземноморського діалогу, Стамбульської ініціативи співпраці, Ініціативи для південно-Східної Європи.

Перед публічною дипломатією альянсу ставилися завдання створення позитивного образу НАТО, роз'яснення урядам і громадським діячам у країнах регіонів суті та цілей кожної з ініціатив з метою зміни ідентичності еліт на користь євроат-

http://journals.iir.kiev.ua/index.php/pol_n/article/viewFile/2769/2473

3 Манойло, А.В. (2008). Психологические операции: модели и технологии управления конфликтами. Политэкс (Политическая экспертиза), 3, 62-73.

4 Pagovski, Z.Z. (2015). Public Diplomacy of Multilateral Organizations: The Cases of NATO, $E U$, and ASEAN. Los Angeles: Figueroa Press.

5 Най, Д.С. (2006). Гибкая власть: как добиться успеха в мировой политике. Новосибирск; Москва: ФСПИ «Тренды».

${ }^{6}$ Strategic Concepts / North Atlantic Treaty Organization: official website. Retrieved from http://www.nato.int/cps/ru/natolive/topics_56626.htm

7 Манойло, А.В. (2008). Психологические операции: модели и технологии управления конфликтами. Политическая экспертиза, 3, 65 . 
лантизму. Паралельно зусилля спрямовувалися на гармонізацію поглядів щодо ключових питань, таких як трансформація НАТО, розвиток миротворчості та врегулювання криз. Всіляко підкреслювалися невійськові аспекти діяльності альянсу. Важливим напрямком було сприяння координації дипломатичних зусиль між НАТО, ЄC і ОБСЕ, пропаганда «нового обличчя НАТО» щодо підтримання миру та гуманітарного втручання.

У рамках подій на Балканах публічна дипломатія НАТО вирішувала завдання роз'яснення цілей і завдань втручання альянсу в справи регіону, що знаходиться за межами традиційної зони відповідальності НАТО. Хиткість аргументації дипломатів НАТО багато в чому була пов'язана як з очевидними протиріччями між діями альянсу в регіоні та міжнародним законодавством, так і відсутністю у альянсу відповідної власної нормативно-правової бази для подібних дій 8 .

Саме тому центральним пунктом стратегічної концепції 1999 р. стало декларування альянсом «права» проводити військові операції за межами території державчленів НАТО. «Право» на проведення таких операцій випливало із закріпленого у концепції нового бачення Організації Північноатлантичного договору як охоронця міжнародної безпеки у глобальному масштабі. Сьогодні НАТО фактично переглянула в односторонньому порядку міжнародно-правову систему європейської та міжнародної безпеки, засновану на Статуті ООН і рішеннях ОБСЄ9 і веде справу до заміни ії альтернативної натоцентричної системи міжнародної безпеки ${ }^{10}$.

Масштабний терористичний акт 11 вересня 2001 р. поклав початок «періоду нових умов безпеки» і поставив перед публічною дипломатією альянсу комплекс завдань по активному залученню до сфери свого впливу нових союзників і партнерів, у тому числі на Кавказі й у Центральній Азії. Були зроблені додаткові дипломатичні кроки щодо поглиблення взаємодії НАТО з міжнародними організаціями, насамперед з ООН, Європейським Союзом та ОБСЕ. Помітна практична спрямованість була додана до заходів, що проводяться під егідою Ради НАТОРосія. Важливий сектор роботи для публічної дипломатії НАТО сформувався, коли, відповідно до мандату ООН, альянс у серпні 2003 р. очолив місію Міжнародних сил сприяння безпеці в Афганістані (МССБ).

Новий імпульс заходам щодо висвітлення та підтримки заходів відносно трансформації військового потенціалу блоку додало прийняття на саміті у Празі «Празьких зобов’язань щодо обороноздатності». У цьому ж руслі формувалися і рішення подальших самітів НАТО з розвитку трьох базових опор альянсу: операцій і місій, військового потенціалу та партнерських відносин.

В основі діючої сьогодні стратегічної концепції «Активне залучення, сучасна оборона» (2010 р.) - політичні та військово-стратегічні установки попередніх доктринальних документів з урахуванням змін військово-політичної обстановки, пов’язаними $з$ терактами у США, війнами в Афганістані та Іраку, «кольоровими революціями» у низці країн. Головна мета - будівництво фундаменту для формування на основі НАТО глобальної військово-політичної організації. При цьому стратегія «ядерного стримування», адаптована до нових умов, продовжує залишатися одним з головних елементів політики США і НАТО ${ }^{11}$.

Поряд зі зміною базових стратегічних параметрів, виведення у 2014 р. контингенту НАТО з Афганістану об'єктивно призвело до поступового зміщення цієї країни до периферії інтересів альянсу та її публічної дипломатії. Проте, Північноат-

\footnotetext{
8 Дай, Т.Р. (2005). Основи державної політики. Одеса: АО «Бахва».

9 Report on Strategic Communication / US Department of Defense: official website. Retrieved from

http://www.au.af.mil/au/awc/awcgate/dod/dod_report_strategic_communication_11feb1o.pdf. ${ }^{10}$ Почепцов, Г.Г. (2008). Стратегічні комунікациї: стратегічні комунікацї̈ в політиці, бізнесі та державному управлінні. Київ: Альтерпрес.

${ }^{11}$ Баровська, А.В. (2015), 148.
} 
лантичний блок поширює використання публічної дипломатії на весь простір «кризової дуги», протяжність якої альянс визначає від зони Сахель (між Сахарою та Суданом) до Центральної Азії. Це вимагає від союзників блоку збереження і вдосконалення всього спектру можливостей публічної дипломатії, в діяльності якої основна увага приділяється підтримці планів розвитку натовського компонента ЄвроПРО, вдосконалення можливостей Сил першочергового використання, проведення великомасштабних навчань. В умовах фінансово-економічної кризи посилився вплив на союзників з метою підтримки на необхідному рівні витрат на військові цілі. Комплекс проведених заходів знаменує своєрідну зміну стратегії публічної дипломатії від інформаційних задач освітлення залученості в конфлікт НАТО до готовності НАТО реалізовувати програми («transition from a deployed NATO to a prepared NATO»)12.

У постбіполярний період відбулася глибока трансформація архітектури органів публічної дипломатії НАТО, задіяних засобів зв'язку та інформації. Традиційно питання про вибір методів і пошуку коштів для виконання завдання інформування своєї громадськості про політику та цілі Альянсу вирішується кожною з країнчленів самостійно. На початку 1990-х років роль Бюро інформації та друку НАТО зводилася, головним чином, до доповнення заходів з інформування громадськості та керівництва повсякденними зв'язками альянсу зі ЗМІ ${ }^{13}$.

У сучасних умовах, окрім НАТО, питаннями публічної дипломатії займається низка національних і міжнародних органів: посольства країн НАТО і РЄАП, національні парламенти та Північноатлантична асамблея, національні Атлантичні ради, комітети або Атлантичні асоціації, інститути та фонди, Відділи інформування громадськості у штабах ОВС НАТО, освітні та навчальні установи Альянсу і національного підпорядкування, а також Асоціація атлантичного договору, міжспілкова Конфедерація офіцерів запасу14.

3 початку 200о-років у штаб-квартирі НАТО в Брюсселі почало діяти Управління публічної дипломатії НАТО, функції якого були істотно розширені, зокрема, за рахунок інформування громадськості з широкого спектру наукових та екологічних програм. Цілями програми «Безпека через науку» були визначені: сприяння безпеці, стабільності та солідарності за рахунок використання потенціалу науки; підтримка демократичних реформ у державах-партнерах НАTO, шляхом налагодження широкоформатного наукового співробітництва; підтримки компютерних мереж і надання грантів. Потенціал програми активно використовується для вивчення обстановки, цілеспрямованого впливу на студентську та наукову громадськість країн партнерів, проведення досліджень у важливих для НАТО напрямах. У Росії та країнах СНД до числа пріоритетних тем включені дослідження міжнаціональних, міжетнічних і міжконфесійних відносин. У рамках грантових програм НАТО у Росії регулярно проводиться зондаж громадської думки з метою координації заходів щодо створення позитивного іміджу альянсу15.

На період 2012 р. натівські програми щодо публічної дипломатії фінансувалися з бюджету НАТО. Кошти виділялися на заходи, які проводилися у самій штабквартирі, співробітниками НАТО, під егідою державних або громадських організацій поза межами штаб-квартири НАТО, а також заходи, організовані іншими зовнішніми установами з безпосередньою або непрямою допомогою НАТО ${ }^{16}$.

12 Ibid, 149.

${ }^{13}$ Babst, S. Public Diplomacy - the Art of engaging and influencing. World Security Network. Retrieved from http://www.worldsecuritynetwork.com/NATO/Atlantic-Community/NATOs-NewPublic-Diplomacy-The-Art-of-Engaging-and-Influencing

14 Pagovski, Z.Z. (2015), 12.

15 Кубышкин, А.И., Цветкова, Н.А. (2013) Публичная дипломатия США: учебное пособие для вузов. Москва: Аспект Пресс, 35.

16 Булатов, О.В. (2012). Регіональна складова глобальних інтеграційних процесів: монографія. Донецьк: ДонНУ, 46. 
Значно зріс потенціал органів публічної дипломатії НАТО у галузі зв’язку та інформації, орієнтований на три основні напрямки: преса та 3МI, міжнародні відносини, поширення інформації в електронній і друкованій формі. Було створено телеканал «NATO-TV», потужний інформаційний сайт штаб-квартири та інформаційні сайти локальних інформаційних бюро й офісів альянсу в країнах РЕАП, поширювалася друкована продукція.

Особлива увага приділяється поглибленню роботи публічної дипломатії на пострадянській території - у Російській Федерації, країнах СНД і державах-членах ОДКБ. Головне завдання при цьому полягає у вивченні обстановки у Росії, країнах СНД та ОДКБ, налагодженні каналів двосторонньої стратегічної комунікації між НАТО і кожним із зазначених акторів, формуванні позитивного та привабливого іміджу Організації Північноатлантичного договору в очах різних груп населення: правлячих еліт, бізнес-спільноти, творчої інтелігенції, військових, молоді. Кінцева мета - зміна ідентичності еліт на користь євроатлантизму ${ }^{17}$.

Протягом останніх років на території колишніх радянських республік була розгорнута широка мережа структур публічної дипломатії альянсу - інформаційних бюро НАТО, місій зв'язку. Створено спеціальні представництва НАТО у країнах Кавказу та Центральної Азїі ${ }^{8}$.

Найбільш широко вся сукупність структурних інституцій публічної дипломатії представлена в Україні, де протягом багатьох років робота ведеться як на рівні еліт, так і «в полі». В їх числі: Центр інформації та документації НАТО, Офіс зв'язку НАТО-Україна, Інститут євроатлантичного співробітництва, Міжпарламентська рада Україна-НАТО, Інститут трансформації суспільства (IT3) з власним мережевим холдингом, що вміщує 53 інформаційних ресурси, Громадська ліга «Україна-НАТО» й ін. ${ }^{19}$

Налагоджена потужна фінансова підтримка з-за кордону. 3 ініціативи IT3 на кошти американського Національного фонду демократії засновані 15 регіональних центрів євроатлантичної інтеграції, переважно з охопленням південного сходу та півночі України. Така тактика укладається у загальну канву інформаційної роботи західних НУО'о.

Публічна дипломатія НАТО покликана підтримувати позитивний імідж організації, демонструвати роль і досягнення військово-політичного блоку в здійснюваних операціях і місіях, підкреслювати нову ідентичність Альянсу та роз'яснювати стратегію його розвитку. На сучасному етапі керівництво НАТО прагне активно застосовувати механізми публічної дипломатії у різних сферах ${ }^{21}$.

На базі цього органу в 2004 р. був створений комітет 3 питань громадської дипломатії (Committee on Public Diplomacy). Одночасно офіс інформації та друку Міжнародного секретаріату перетворений в управління з питань громадської дипломатії, що більш повно відображало його цілі та завдання.

На даний час комітет з питань громадської дипломатії, який працює під керівництвом Ради НАТО, є головним консультативним органом блоку з проблем інформаційно-пропагандистської діяльності та співпраці із засобами масової інформації. Він вивчає стан інформованості населення держав-учасниць та інших країн про політику альянсу і координує зусилля, спрямовані на створення позитивної громадської думки про Альянс. Комітет розробляє для Ради НАТО рекомендації щодо розширення діяльності організації в інформаційній сфері, у тому числі з пи-

\footnotetext{
17 Щетинин, В.Д. (2001). Экономическая дипломатия. Москва: Международные отношения, 63.

18 Почепцов, Г.Г. (2008), 71.

19 Баровська, А.В. (2015), 148.

${ }^{20}$ НАТО-Украина. Новые не афишируемые реалии. Gubkin.info. Retrieved from http://gubkin.info/politics/84379-nato-ukraina-novyeneafishiruemye-realii.html

${ }^{21} \mathrm{O}$ расширении НАTO. Retrieved from http://nato.weurope.org/show.php?art=104\&rubr=33
} 
тань ведення психологічної боротьби. Його засідання проводяться на рівні представників національних делегацій із запрошенням експертів 3 відповідних відомств країн блоку. Головою комітету є помічник генерального секретаря - начальник управління з питань громадської дипломатії Міжнародного секретаріату НА$\mathrm{TO}^{22}$.

Важливим завданням даного комітету є розробка інформаційних стратегій, які оновлюються кожні два роки та затверджуються Радою НАТО. Дані програмні документи мають типову структуру і розкривають найбільш гострі інформаційні проблеми альянсу, оцінюють його інформаційні можливості, визначають пріоритетні галузі інформаційної роботи на майбутній період, вказують основні цільові аудиторії, уточнюють засоби та методи інформаційного впливу на них.

Загальну спрямованість і способи інформування громадськості про політику та практичних заходах альянсу визначає Рада НАТО. У його підвідомчих структурах засновані й активно функціонують посадові особи, які безпосередньо вирішують інформаційні завдання відповідно до затвердженої коаліційної стратегією громадської дипломатії 23.

Помічник генерального секретаря НАТО з питань громадської дипломатії відповідає за координацію між цивільними та військовими структурами стратегічної пропаганди у межах повноважень Ради НАТО і генерального секретаря організації. Він забезпечує узгодженість і максимальну ефективність дій Військового комітету, Міжнародного військового штабу, командувань Альянсу та інших керівних структур, відповідальних за планування та проведення операцій у галузі стратегічної пропаганди.

3 цією метою управління налагодило тісну співпрацю з усіма лояльними 3МI, організовує видання та поширення друкованої продукції, а також підтримку інформаційного сервера альянсу в мережі Інтернет, проводить масові заходи, які висвітлюють військову політику організації. Управління також займається аналізом повідомлень 3МІ і надає його результати до вищого військово-політичного керівництва блоку, розробляє рекомендації щодо підвищення ефективності використання медіа-засобів для проведення пропагандистської роботи.

До складу цієї важливої керівної структури входять: апарат управління (секретаріат, група радників, фінансове відділення); прес-центр (відділи по роботі з пресою та аналізу повідомлень 3MI); служба інформації (відділи редакційний та інформаційних технологій); напрямок регіональної співпраці (три відділи - організації заходів, програм співробітництва, супроводу делегацій). Керівнику напрямку регіонального співробітництва також підпорядковані Інформаційне бюро в Москві, Центр інформації та документації в Києві, інформаційні центри в країнахучасницях НАТО та партнерських державах.

Висновки. Отже, за період існування НАТО, публічна дипломатія зазнавала своїх піків, а саме на початку їі розвитку. Реалізація публічної дипломатії НАТО здійснюється не лише в межах самого Альянсу, але й залученні інших міжнародних організацій. Головним завданням у сприянні публічної дипломатії НАТО $\epsilon$ поширення вагомого значення організації на сучасній арені міжнародних відносин у питанні забезпечення миру в світі. Варто зазначити, що публічна дипломатія залишається основним інструментом для вирішення глобальних суперечок, особливо у військовій сфері.

\section{REFERENCES}

Babst, S. (2009, February 24) Public Diplomacy - the Art of engaging and influencing. World Security Network. Retrieved from http://www.worldsecuritynetwork.com/NATO/AtlanticCommunity/NATOs-New-Public-Diplomacy-The-Art-of-Engaging-and-Influencing

22 Почепцов, Г.Г. (2008), 89.

23 Гуцал, С. (2015), 9. 
Barovska, A.V. (2015). Stratehichni komunikatsii: dosvid NATO [Strategic communications: NATO's experience]. Stratehichni priorytety, 1 (34), 147-151 [in Ukrainian].

Bulatova, O.V. (2012). Rehionalna skladova hlobalnykh intehratsiinykh protsesiv: monohrafiia [Regional component of global integration processes: monograph]. Donetsk: DonNU [in Ukrainian].

Hutsal, S. (2015). Publichna dyplomatiia ta stratehichni komunikatsii: vyznachennia kontseptualnykh osnov [Public diplomacy and strategic communications: defining conceptual foundations]. Mizhnarodni vidnosyny. Seriia «Politychni nauky»,9. Retrieved from http://journals.iir.kiev.ua/index.php/pol_n/article/viewFile/2769/2473 [in Ukrainian].

Kubyshkin, A.I. \& Tsvetkova, N.A. (2013). Publichnaya diplomatiya SShA: uchebnoye posobiye dlya vuzov. [US Public Diplomacy: A Study Guide for Universities]. Moskva: Aspekt Press [in Russian].

Manoylo, A.V. (2008). Psikhologicheskiye operatsii: modeli i tekhnologii upravleniya konfliktami [Psychological Operations: Models and Technologies of Conflict Management]. Politicheskaya ekspertiza, 3, 62-73 [in Russian].

Nay, D.S. (2006). Gibkaya vlast: kak dobitsya uspekha $v$ mirovoy politike. [Flexible Power: How to Succeed in World Politics]. Novosibirsk; Moskva: FSPI «Trendy». [in Russian].

Pocheptsov, H.H. (2008). Stratehichni komunikatsii: stratehichni komunikatsii v politytsi, biznesi ta derzhavnomu upravlinni [Strategic communications: strategic communications in politics, business and public administration]. Kyiv: Alterpres [in Ukrainian].

Pagovski, Z.Z. (2015). Public Diplomacy of Multilateral Organizations: The Cases of NATO, $E U$, and ASEAN. Los Angeles: Figueroa Press [in English].

Shchetinin, V.D. (2001). Ekonomicheskaya diplomatiya [Economic diplomacy]. Moskva: Mezhdunarodnyye otnosheniya [in Russian].

\title{
Olesia Zvezdova, Petro Mohyla Black Sea National University, Mykolaiv, Ukraine ORCID: https://orcid.org/oooo-ooo1-9664-5257
}

\author{
Alona Mokryak, \\ Petro Mohyla Black Sea National University, Mykolaiv, Ukraine \\ ORCID: https://orcid.org/oooo-Ooo2-3679-0919
}

\section{The evolution of NATO public diplomacy}

In modern conditions, public diplomacy is becoming an important structural component of the strategy of leading actors in world politics, including the North Atlantic Treaty Organization (NATO). There are several periods, each characterized by its own block of goals and objectives of public diplomacy, the direction of their development in accordance with the evolution of the strategic attitudes of the bloc as a model of collective security, such as the Cold War, the "period immediately after the Cold War and cooperation" in NATO terminology) and the period of globalization (or the "period of new security conditions after 11.09.2001» in NATO terminology).

NATO's public diplomacy includes a set of forms and methods, forces and means of propaganda, as well as the means of group communication used to explain NATO's policies, assist in military operations and other tasks. This activity is aimed at forming a «correct understanding» by the target audiences of NATO's practical steps to maintain a stable situation in crisis regions, which eliminates hostility on the part of local leadership and the population towards the bloc's troops.

In 1991 and 1999, NATO's strategic concepts were adopted, based on the political and military-strategic settings of the «flexible response» strategy, supplemented by changes in the military-political situation after the end of the Cold War. The largescale terrorist attack of 11 September 2001 marked the beginning of a "period of new security conditions» and set the alliance's public diplomacy a set of tasks to actively engage new allies and partners, including in the Caucasus and Central Asia. 
An important area was to promote the coordination of diplomatic efforts between NATO, the EU and the OSCE, and to promote the «new face of NATO» in peacekeeping and humanitarian intervention.

Keywords: NATO, public diplomacy, information strategy, public diplomacy bodies 